

\section{STUDIA UNIVERSITATIS HEREDITATI}

Znanstvena revija za raziskave in teorijo kulturne dediščine

Letnik 5 , številka 2, 2017

Studia universitatis hereditati je humanistična znanstvena revija za raziskave in teorijo kulturne dediščine z mednarodnim uredniškim odborom. Objavlja znanstvene in strokovne članke s širšega področja kulturne dediščine (arheologija, arhitektura, etnologija, jezikoslovje, literarna, kulturna, glasbena, intelektualna, religijska, vojaška zgodovina, zgodovina idej itn.) in pregledne članke ter recenzije tako domačih kot tujih monografij z omenjenih področij. Revija izhaja dvakrat letno. Izdajata jo Fakulteta za bumanistične studije (Oddelek za arheologijo in dediscino) in Založba Univerze na Primorskem.

Poglavitni namen revije je prispevati k razvoju raziskav kulturne dediščine v najširšem in k topoglednemu interdisciplinarnemu pristopu $\mathrm{k}$ teoretičnim in praktičnim raziskovalnim vprašanjem. Tako revija posebno pozornost namenja razvoju slovenske znanstvene in strokovne terminologije, konceptov in paradigem na področju raziskovanja kulturne dediščine v okviru humanističnih ved.

\section{Glauni in odgovorni urednik}

dr. Gregor Pobežin (Fakulteta za humanistične študije Univerze na Primorskem, Koper)

Urednici stevilke

dr. Zrinka Mileusnić in dr. Alenka Tomaž (Fakulteta za humanistične študije Univerze na Primorskem, Koper) Tehnična ureditev revije, oblikovanje in prelom

dr. Jonatan Vinkler (Fakulteta za humanistične študije Univerze na Primorskem, Koper)

Lektor (slovenska besedila)

Davorin Dukič (Univerza na Primorskem, Koper)

\section{Uredniski odbor}

dr. Zdravka Hincak (Filozofski fakultet, Sveučilište u Zagrebu), dr. Matej Hriberšek (Filozofska fakulteta, Univerza v Ljubljani), dr. Katja Hrobat Virloget (Fakulteta za humanistične študije Univerze na Primorskem, Koper), dr. Irena Lazar (Fakulteta za humanistične študije Univerze na Primorskem, Koper), dr. Maša Sakara Sučevič (Pokrajinski muzej, Koper), dr. Alenka Tomaž (Fakulteta za humanistične študije Univerze na Primorskem, Koper), dr. Tomislav Vignjevič (Fakulteta za humanistične študije Univerze na Primorskem, Koper), dr. Jonatan Vinkler (Fakulteta za humanistične študije Univerze na Primorskem, Koper), dr. Paola Visentini (Museo Friulano di Storia Naturale, Udine)

Izdajatelj: Univerza na Primorskem - Založba Univerze na Primorskem (za Fakulteto za humanistične študije Univerze na Primorskem)

(C) 2017 Založba Univerze na Primorskem

Zanjo: prof. dr. Dragan Marušič, rektor

Titov $\operatorname{trg} 4$

SI-6000 Koper

ISSN $2350-5443$

DOI: https://doi.org/10.26493/2350-5443.5(2)

\section{(c) (i) $\circledast$}


studia universitatis hereditati 



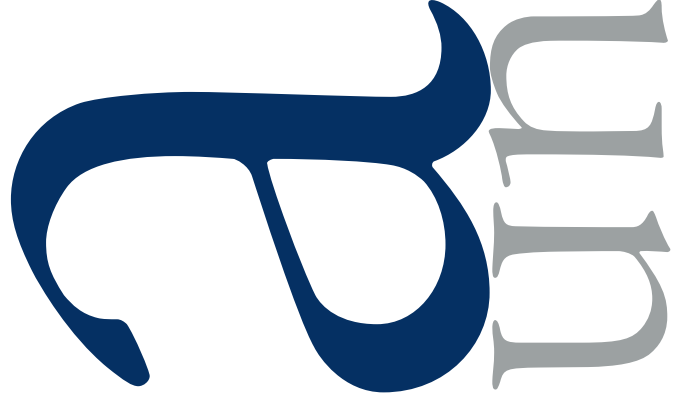

○
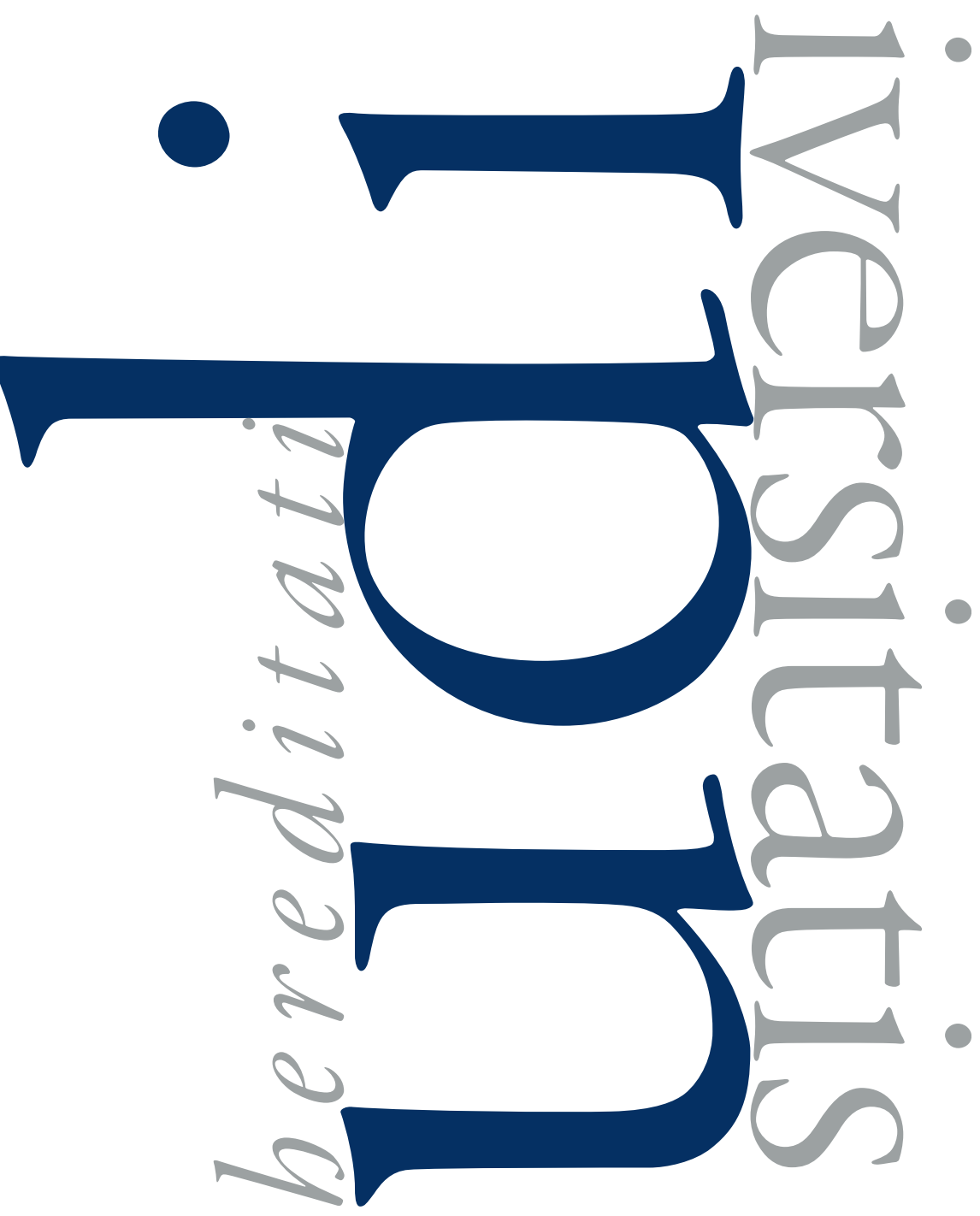

LETNIK 5

ŠTEVILKA 2

LETO 2017
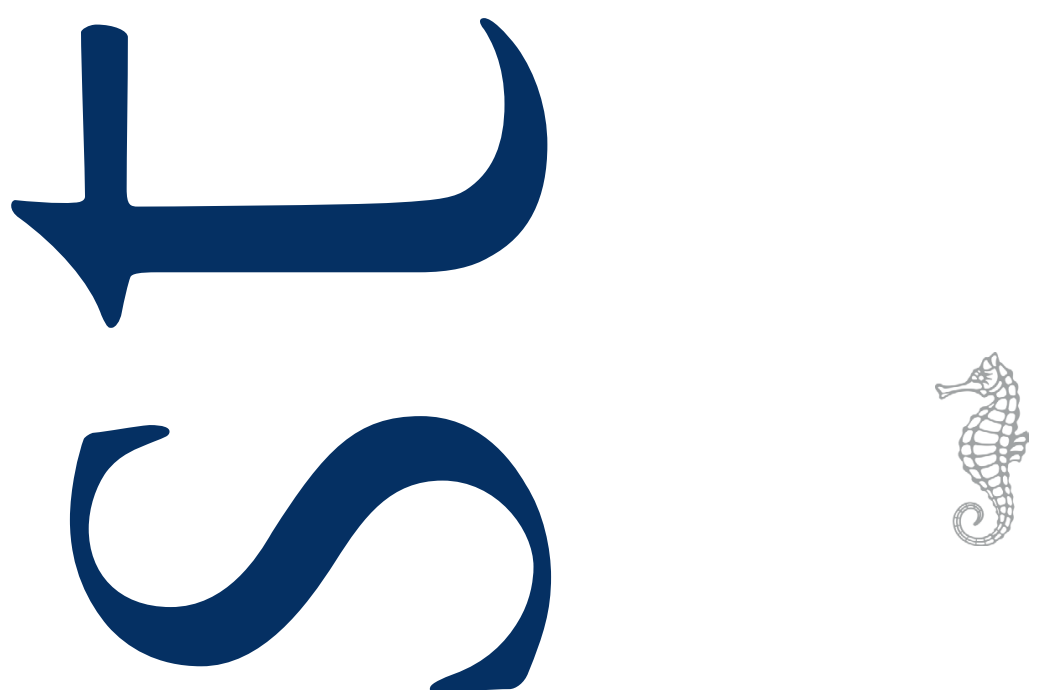
-

r

$\downarrow$

G

1

-

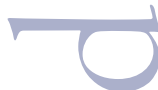

( )

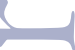

(U)

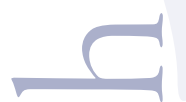




\section{Vsebina/Contents}

Julijana Visocnik, Bernarda Zupanek, Simona Jarc in Luka Gale

9 Rimski fragmenti z napisi v Mestnem muzeju Ljubljana

Jadranka Cergol

2 I I cambiamenti etnici sulla penisola Italica dalla guerra sociale alla morte dell'imperatore Augusto

Miba Mlinar

37 Rimski grob z zrcalcem z Lipičarjevega vrta na Mostu na Soči

Zdravka Hincak in Kresimir Filipec

47 Forensics and Archaeology: The Ethical Approach to Graves Excavation and Research Zorana Dimković

59 Nevidljiva dugovečnost u arheološkom kontekstu

Alenka Tomazin Maśa Sakara Sućevic

7I Arheološke raziskave na lokaciji Kaštelir nad Kortamiv letu 2014

Nenad Joncić

IOI Implementation of 3 D Scanning in Presentationand Preservation of Cultural Heritage Case Study: Dungeons of the National Museum in Pančevo 
-

r

$\downarrow$

G

1

-

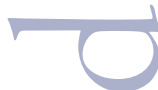

( )

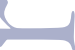

(U)

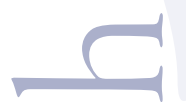




\title{
Forensics and Archaeology: The Ethical Approach to Graves Excavation and Research
}

\author{
Zdravka Hincak, University of Zagreb, Faculty of Humanities and Social Sciences
} Krešimir Filipec, University of Zagreb, Faculty of Humanities and Social Sciences

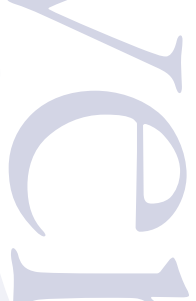

Ali obstaja razlika med metodami in tehnikami, ki se uporabljajo v arheologiji in forenzični arheologiji? Opisan je grob z arheološkega najdišča Josipovac - Verušed pri Osijeku (Slavonija, Hrvaška) odkrit leta 2007 , ki prepleta oz. povezuje obe področji. Med zaščitnimi arheološkimi izkopavanji na trasi avtoceste (A 5) Beli Manastir - Osijek so odkrili grob neznanega vojaka iz druge svetovne vojne. Pojasnjen je pomen poudarjanja konteksta, ki je omogočil umestitev odkritij oz. najdb v forenzični okvir. Po primerjavi metod, tehnik in tehnologij, ki jih uporabljata arheologija in forenzična arheologija, smo poskušali ugotoviti, kaj pomenita etika in bioetika za obe disciplini ter kako razmišljati o teh pojmih v arheološkem smislu.

Ključne besede: forenzična arheologija, grob, etika, druga svetovna vojna

Is there a difference between the methods and techniques used in archeology and forensic archaeology? A grave from archaeological site Josipovac - Verušed near Osijek (Slavonia, Croatia) in 2007, which permeates both areas was described. The burial pit of an unknown soldier from World War II was revealed during an archaeological rescue excavation on the route of the highway (A 5) Beli Manastir - Osijek. The importance of giving emphasis to the context, which enabled classification of the findings in the forensic framework, was explained. After the comparison of methods, techniques and technologies used by both archaeology and forensic archaeology, we have tried to determine what meaning have ethics for the two disciplines, as well as how to think about these concepts in the archaeological sense.

Key words: forensic archaeology, grave, ethics, World War II

$\mathrm{D}$ evelopment of the archaeological field methods and techniques did not follow the interest of beautiful, antique, valuable objects that interested antiquarians from the very beginning. Indeed, since the prehistoric times, archaeological sites' and graves' robbers have mercilessly devastated the world heritage. But if we mention the history of archaeological research we also need to mention the first archaeological excavations of the civilizations that left their ruins in the Mediterranean, in the Middle East and later, in Americas.
The first organized archaeological excavations were carried out in Croatia at the I9th century and they slowly laid foundations for today's surveys, introducing the very base of archaeological methods of the field research: setting up a one-meter grid square for excavation or a baseline offset. Together with classical tools for manual excavating, such as shovels, digging spades or mattocks, there are also mentioned small excavation tools for fine digging and cleaning, a simple trowel or a brush to sweep the dirt.

The archaeological field research shows not only what has remained after people who 
lived in a certain area, but also, using the physical traces of past societies, reconstructs events, examines what people did in a particular area, how did they think, and lived. All this can be read from an archaeological site; it is important to leave findings in situ, to record them, to document all the small pieces that later, put together, will give much more data. Similar to piecing together evidence in forensics. The archaeological field methods became a part of the forensic investigation tools before archaeologists did. According to the definition, the forensic archaeology is an application of the archaeological paradigms, methods and goals to the questions of medico-legal significance.

But a possible problem for an archaeologist involved in forensics, the medico-legal investigation, are not different methods or new technologies in the field work. Huglund explains it well: "Archaeological context in a forensic case includes the rules of evidence, the chain of custody, the potential that a court testimony may be required, and the fact that the activities and work of archaeologists may be subjected to legal scrutiny." Archaeologists got involved and became more frequent members of forensic teams during the 1990s, often united with physicians, odontologists, radiologists and criminalists in the investigations of human rights' violations, or revealing the evidence of mass murders as in Rwanda, Bosnia and Herzegovina, Croatia. With a strong contribution in developing recovery techniques at crime scenes and knowledge to elaborate techniques for the excavation of sites, forensic archaeology has a possibility to become a sub-discipline. Today, the unwritten criteria for a forensic archaeologist is to spend at least three full years of fieldwork on sites encompassing open sites, structural sites, burial sites, caves, and well or latrine sites.

Melissa Connor and Douglas D. Scott, "Paradigms and Perpetrators," Historical Archaeology 35, no. I (2001): I-6.

William D. Haglund, "Archaeology and Forensic Death Investigations," Historical Archaeology 35, no. I (2001): 26-34

Douglas D. Scott and Melissa Connor, "The Role and Future of Archaeology in Forensic Science," Historical Archaeology 35, no. I (200I): $10 \mathrm{I}-104$

\section{Material and methods}

The archaeological site Josipovac - Verušed is situated southwest of Josipovac (AN I5) in Slavonia region, Croatia. In the past, it was a village, and today it is a suburb of the town of Osijek in Osijek - Baranja County. Rescue excavations were performed on this site from 2007 to 2008 , on the route of the highway Beli Manastir - Osijek. The excavated area occupied $171000 \mathrm{~m}^{2}$ (Fig I). During the excavation of this large prehistoric and medieval settlement, a grave of a soldier from World War II was discovered. This finding was unexpected for an archaeological site, so all standard procedures that precede an excavation had already been made. Following the sequences of archaeological layers, contours of a possible burial pit emerged as a darker layer of earth (Fig 2). Analysis of its relations to other geological and cultural layers showed that it was not an old cultural layer from the Prehistoric, Roman or Medieval period. Immediately a doubt emerged, it was possible that the finding was a recent burial (in archaeological terminology recent burials are about 50-60 years old, up to a maximum of Ioo years old). The appearance pattern of burial pits from past wars (World War II and the Croatian War of Independence) is well known in that part of Slavonia, from previous archaeological excavations. It is a consequence of taphonomy - decomposition of the body and other natural processes.

Deposits of earth were removed by machine and lately by hand. It is important to mention that in the stratigraphic sequences, after exposition of human remains in double graves, trace boundaries between each skeleton or anatomical element were set. The excavation of the specific burial pit was carried out using traditional archaeological methodology, removing layer after layer and documenting each stage of work with photographs and drawings. From the photographs it is evident that the excavation and the exhumation did not just blindly follow the stratigraphy, but also the body extension, which was later of a great help to the anthropologist, providing an opportunity to obtain additional data 
on the individual. At the end of the research, the position of the skeleton and the burial pit were recorded with a total station or TST (TST Leica TCR805 and multi-element array antennas for GPS recording Leica System 900 GNSS), a distance measuring and diverse mapping electronic theodolite. TST is also used for precise measuring of objects in small excavations. Now, the finding - the skeleton and the burial pit - were located in the area in relation to the geographical points. The documentation was extensive, with complete burial sheets and application forms. The grave was given a number, it was marked as VE '07, grave Io with excavation data I8th October 2007 and basic information on its orientation, circumstances of the finding and basic anthropological analysis (approximate age at death and sex). In the forms were written data about the method of excavation. After a thor- ough cleaning of the burial pit and the skeleton in situ, the finding was drawn and photographed with a digital camera. Selected targets, the photo points, were recorded with a total station and fed into the GIS system (Geographical Information System) that covers the entire site and a wider region, as well as the whole county. Several times during the excavation, after finishing each major phase of the research, photogrammetric surveying of the site was made, using light aerial platforms. In this specific research, it included a system with helium-filled balloons and a Picavet platform (NCP case), and also the help of a paraglider (Fig I,2). In both cases, photographs were taken with a professional digital camera Canon EOS $\mathrm{ID}$. Photographs are stored in the Phototeque of Department of Archaeology (Faculty of Humanities and Social Sciences, University in Zagreb).

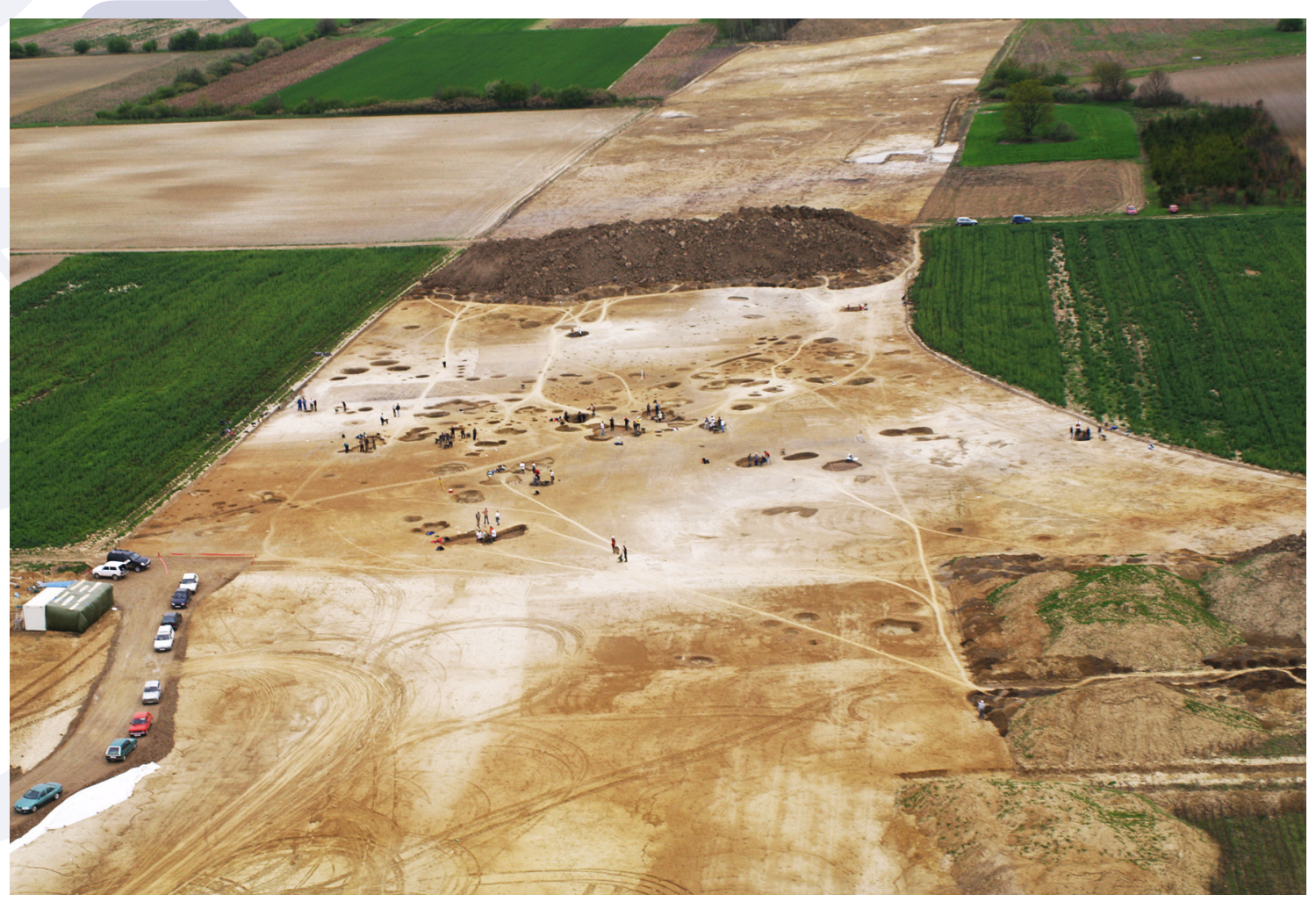

Figure i. Aerial view of the archaeological rescue excavation on the site Josipovac - Verušed (Phototeque, Department of Archaeology, Faculty of Humanities and Social Sciences, University in Zagreb, 2007). 


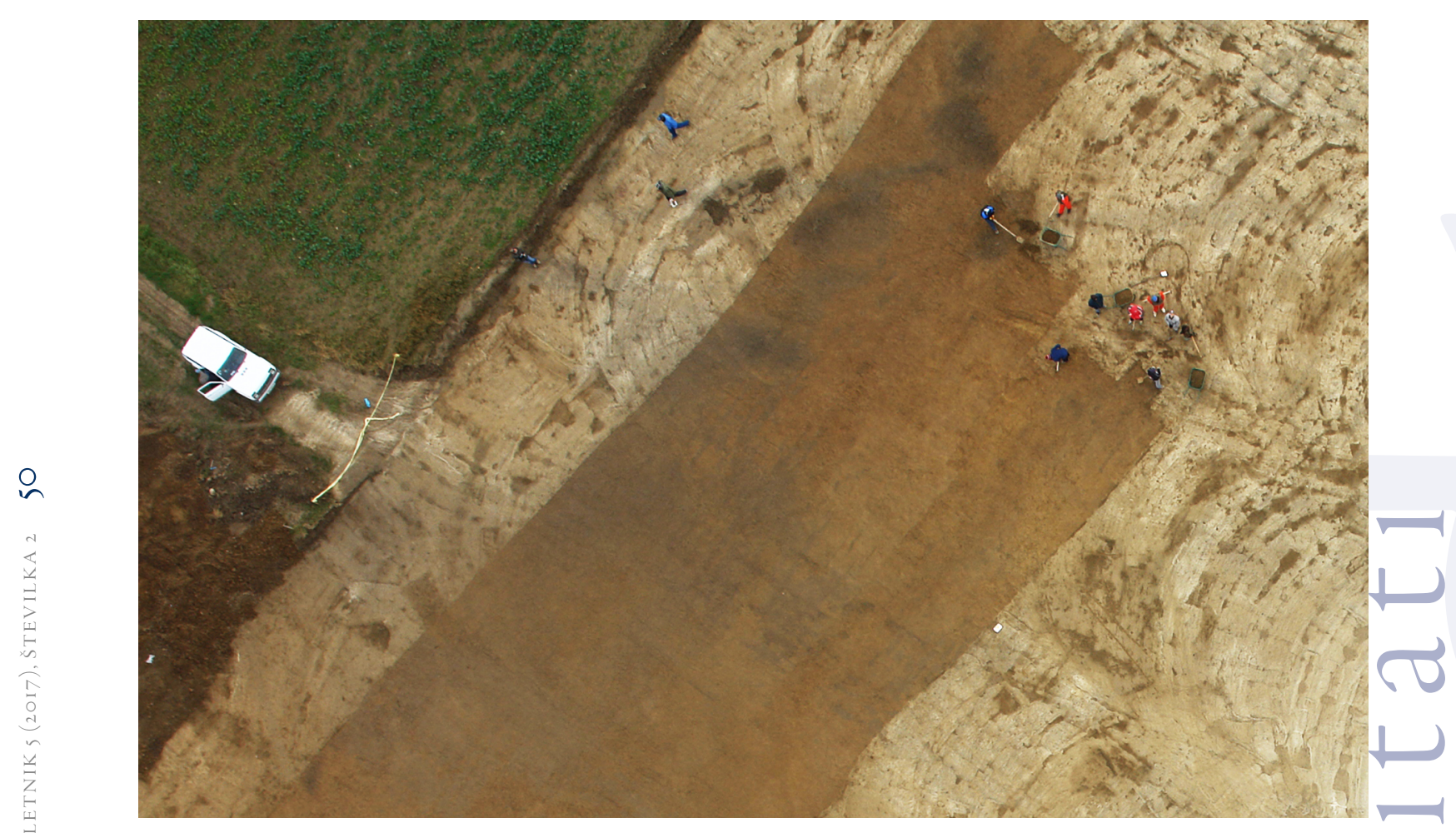

Figure 2. Aerial view of the polished surface of the ground before escavation on the site Josipovac - Verušed (Phototeque, Department of Archaeology, Faculty of Humanities and Social Sciences, University in Zagreb, 2007).

\section{Results}

The described possible finding of a recent age on the site Josipovac - Verušed was treated as a real archaeological, historical layer, since prior the excavation there was no information that could confirm its age. Cleaning began and after removing the topsoil layers at the earth surface, soil with specific characteristics was revealed, such as dark colour, greasy appearance and consistency, affirming it was very probably a burial (Fig 2). This burial was not deep, in fact, it was very shallow and layer contours emerged immediately after removing layers of ploughing (approximately on thirty to forty centimetres of depth). After defining the entire pit on the surface, only a part was sorted out to see its content. Therefore, the grave was not being excavated all at once, first, a smaller probe was made in the part where the best results were calculated. In a small probe that had scarcely $20 \mathrm{~cm}$ in width and about $10 \mathrm{~cm}$ in depth human remains were found. They were a part of a badly preserved shin (tibia), due to the shallowness of the grave. The probe encircled the area near the legs. The entire outline of the dark soil had a north-south orientation and there was no longer any doubt that it was a burial pit. After that, the whole pit was defined so that its entire surface was lowered and the layer of soil slightly removed. A bigger surface of the grave was covered with dark soil and a smaller one with lighter soil or subsoil, which was transferred from the deeper layers to the surface. That lighter layer differed from the real subsoil just in a hardness degree.

After the entire burial pit was defined, its final form was seen as a form of a fairly broad and rectangular grave. This was in contrast to our original thesis that it was an emergency burial. During further cleaning of the grave's surface, and removing of a layer of earth 2 to $3 \mathrm{~cm}$ 
thick, several iron items were found, close to the skeleton, at the level of its legs. There was a tube that looked like a barrel of an automatic firearm, or as a fragment of a firearm used in World War II. So when, after defining skeleton remains, remains of a firearm emerged from the soil, the Ministry of the Interior, the police, had to be informed, because it was obvious that the skeleton belonged to a victim of World War II or the post-war period. Indications for dating the grave at that time were indisputable, due to the typization of armament found in it. The excavation continued according to the archaeological methodology, starting from the legs' position. In archaeological research skeletal remains are cleaned from the feet to the head. According to the preliminary anthropological analysis, the skeleton belonged to a male person aged 30-40 years at the time of death. In its grave, the skeleton was laid on the back and close to it more small metal objects were detected (Fig 3 ).

In the shoulder area, close to the upper part of the chest, a small iron emblem was found. It was quite corroded, yet it still had clear outlines reminiscent of a bird of prey, maybe an eagle. The skeleton was completely cleaned according to archaeological research methods. Metal buttons were detected at several positions close to the skeleton: three at the level of both shoulders, two at the chest level, two on the right humeral bone and six more, almost in line near the spine on both sides, from the suprasternal notch to the waist level (Fig 4). The soil around and close to it was also removed and levelled with the skeleton. Since the grave was shallow, when a ploughing layer of $30 \mathrm{~cm}$ was removed, a very thick layer of about $10-15 \mathrm{~cm}$ for the burial itself remained. The skeleton was very poorly preserved, so it was more like a medieval burial than from the years 194I-1945. Each segment of the work was carefully performed, checking several times so as not to miss anything. Each phase was documented with description, photographs and drawings. A detailed plan and profile (cross-sectional) maps of the skeleton were made before it was removed. In the end, the final image, a photograph of the

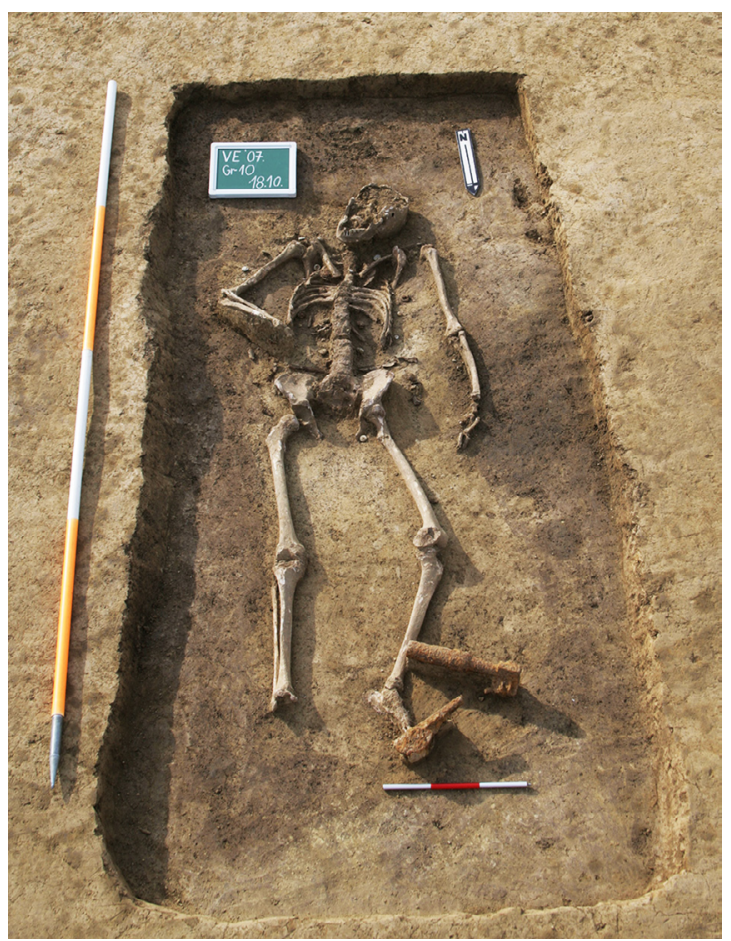

Figure. 3. Grave io- the skeleton of a German soldier in situ (Photo: Krešimir Filipec, 2007).

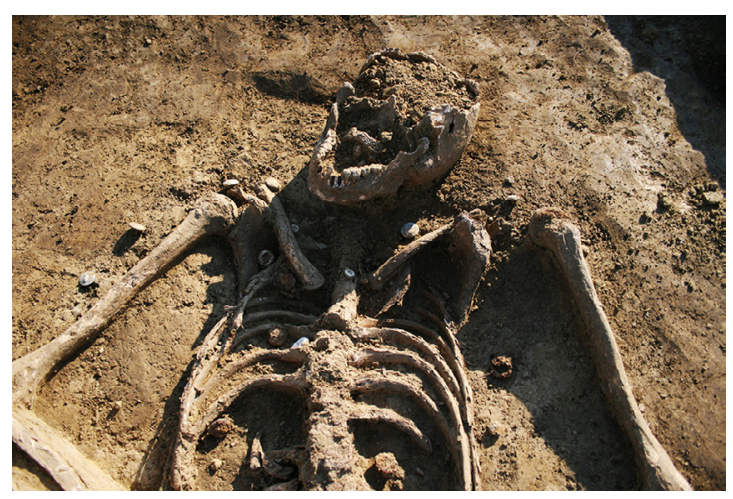

Figure. 4. Grave Io- the upper part of the skeleton of a German soldier in situ (Photo: Krešimir Filipec, 2007).

entire burial pit with the skeleton was enclosed in the documentation. After being stabilized and raised, the skeletal remains were taken to the pathologist of the Department of Pathology and Forensic Medicine (Clinical Hospital Osijek) for further analysis. Afterwards, the excavation, 
or better, cleaning, was continued, because it was obvious that at the bottom of the defined grave new pits emerged as a dark layer - black oily soil, organic residues or maybe humus - which from the upper layers could have reached the lower ones. The first layer was located close to the right leg, the second close to the left hand, and the third around the place where the skull of the deceased person was placed. In the empty pit, close to the bones of the right leg, small metal objects were found, but with no potential for further analysis. A similar composition was found close to the bones of the left hand, the pit was dug to the bottom but no other artefacts were detected; if there was any organic material laid in the pit, it had not been preserved. In the third pit, discovered under and near the skull, immediately after the raising of the skeleton, corroded iron objects were found. Deeper digging revealed firearms' ammunition: about twenty anti-aircraft bullets and twice as many bullets of various calibers for machine guns and rifles. The ammunition was unused, spent shells were not found. Close to the bullets, some organic material was found, remnants of the leather cases for ammunition and parts of a belt. All the ammunition was documented, measured and photographed. As all the ammunition was unused and poten-

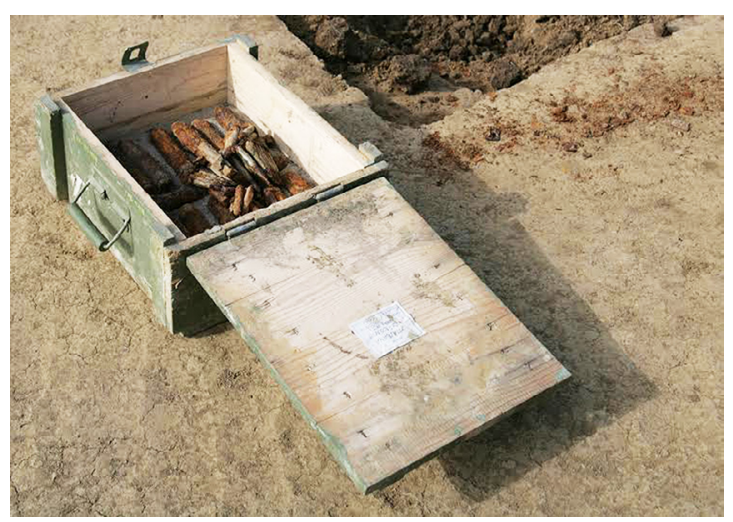

Figure. 5. Storing of ammunition from the burial pit before its safe destruction (Photo: Krešimir Filipec, 2007).

tially very dangerous to the environment, an official pyrotechnist arrived on the archaeological site and destroyed it near the grave (Fig 5). After the third pit was completely emptied, it was possible to come to some conclusions.

\section{Discussion and Conclusion}

The grave was excavated in a field and according to preliminary data the body was placed within during the last century. The burial pit was shallow and it had unusual orientation. Somewhat similar situations were described at other archaeological locations, such as on the site Stari Perkovci - Debela šuma in Brod-Posavina county, but at first glance, this was a slightly different case. In Stari Perkovci - Debela šuma the discovered person was killed and buried in a shallow pit. The pit configuration was quite irregular, and it was clear that digging and burial had been done in haste. ${ }^{4}$ But the burial pit was spacious enough to throw the body into, positioned on its side, and cover it with earth. That case also appertains to the victims of World War II or the post-war period. But there are a few noticeable differences between the two cases. The burial pit from Josipovac - Verušed near Osijek is also located not in the cemetery but in a field, yet its contours show a neat, precise digging work, though indeed shallow. However, this pit is wide and long enough to lay the body on its back in extended position. Metal buttons were detected at several positions close to the skeleton, as it was mentioned before: three at the level of both shoulders, two at the chest level, two on the right humeral bone and six more, almost in line near the spine on both sides, from the suprasternal notch to the waist level. The position of the buttons indicates remains of the short upper part of a military uniform with epaulettes. Also, after further research, a thesis was set about the iron, corroded emblem in the shape of an eagle. This emblem was most probably positioned on the cap or was a part of the military uniform. The burial was preliminarily defined as a burial of an unknown soldier. The person who buried his dead body first dug a grave with

Krešimir Filipec and Marija Šiša-Vivek, „Report on the archaeological site Debela šuma," Hrvatski arbeološki godišnjak no. 3 (2006): 69$7 \mathrm{I}$. 
three smaller pits inside, into which he laid ammunition, parts of the holster with bullets, and any other object of organic origin. The organic material, including soft tissues of the body, decomposed very quickly, not only because of the shallow burial and the effects of the weather conditions but also because of the high acidity of the soil. The gravedigger put ammunition and organic material in the pit, which had to be collected from the wider area, obviously after a battle. Over it, he laid the dead body and next to him the fragments of destroyed weapons. After the archaeological excavation and research, this is beyond dispute. All phases of the work were documented and photographed so that nothing misses. The skeletal remains of the deceased, the weapon components, the metal buttons and the corroded emblem were stored under the protocol for possible subsequent analysis that could get more information about the person and the circumstances of his burial. On this archaeological site, no similar burial pits were found. However, about a thousand meters eastward, towards Osijek, a military bunker from World War II is still preserved. It was an assumption that maybe the death of the buried person was related to broader events in the area at that time. With subsequently conducted archival research we found out what probably happened in that marginal area of the town of Osijek, west of Josipovac. The theory was set that it was the grave of a soldier from World War II. For a moment, consider the corroded iron emblem with, most probably, depiction of an eagle. In the archive files, it was mentioned that the II $^{\text {th }}$ German Air Force Division was situated in Osijek and participated in the battles for the city. With advancing of the People's Liberation Army and Partisan Detachments of Yugoslavia toward Osijek, in the last days of World War II, a combat began in which many soldiers were killed. On the photograph published in the book of Petrov, in descriptions and on additional photographs, captured German soldiers in the underwear can be seen. ${ }^{5}$ Some-

Marinko Petrov, Pakao na Dravi Belišce 1944-1945 Bistrinci (Bački Petrovac: Mesno udružnje boraca NOR-a Belišće, 1979), I 42-1 47. how the situation could be similar to the case of Josipovac - Verušed: a soldier that was killed in a battle, or executed after it, and then buried by a villager in his plough-field or along its edge.

As mentioned earlier, at the very beginning, the orientation of the grave was North-South. Such grave orientation follows the orientation of the plough-fields in that area. It indicates that the soldier was buried in a part of the field not used for cultivation, to avoid unpleasant situations. It is quite possible that the villager who burried him was an owner of that plough-field where the battle occurred. Afterwards, he might have collected all explosive and unexploded ammunition scattered around and buried them beneath the killed soldier. Unfortunately, it was not possible to do any further research, a survey, about this case with the locals, because the majority of the inhabitants of the village Josipovac were expelled after the end of World War II. Namely, in Josipovac had lived members of the German minority in Slavonia. These are assumptions after the archaeological excavation and research were done.

The described methods of research belong to archaeology, from the preparation of a site to the fieldwork. But in this particular case some very important phases of forensic archaeology are missing, such as the area location, the site location and the confirmation, because this grave was found by chance on an archaeological site. These phases include not only location and confirmation but also a determination of its nature. Both archaeological sites and forensic crime scenes, f.e. mass grave's vicinity, contain valuable evidence like fragments of clothing, various objects or personal items.

While in archaeological field research the use of modern methods and techniques depends largely on financial possibilities, in forensics they are a must. Development of nonintrusive or non-destructive tools gives a possibility to see through the layers of the ground, without destroying the site. In the area and site location, forensic archaeologists use several tools like area imagery taken by the aerial reconnais- 
sance platforms. From the air, it is possible to explore anomalies in the ground, such as the disturbed land of mass grave trenches. So, instead of described helium balloons with a platform in the case of the unknown soldier from Josipovac, it is possible to use drones. On the site, soil geochemistry could be analyzed by the use of a handheld X-ray fluorescence spectrometer (XRF). It detects traces of human and animal activities (like faeces) in the ground measuring the elemental composition of the soil or an artefact/evidence. On the site, it is possible to determine the extent of an activity or an object using radar pulses to image the ground, with a ground penetrating radar (GPR) and other geophysical techniques. Tools for the shallow geophysics on the site measure ground resistivity and thus can reveal buried structures just like the electrical resistant survey. ${ }^{6}$ Other alternative techniques are time-lapse resistivity and remote sensing. The last one includes several very popular technologies, like aerial photographs, ultraviolet (UV) and infrared (IR) photography, satellite and hyperspectral imagery, light detection and ranging (LiDAR). LiDAR in a fraction of time gives detailed ${ }_{3} \mathrm{D}$ maps of the site surface and can easily locate clandestine and mass graves.

Documentation, as it was explained in the case, is of great importance during this work. Forensic forms are even more detailed: about preservation degree, taphonomic processes (a body or a part of a body, clothes), other evidence on human remains (tattoos, ligatures, a blindfold, position). This is called in situ evidence. The excavated earth has to be sifted, as in the case of material from the burial pit of the unknown soldier from Josipovac. After the excavation of the skeleton in the case, the profile and the floor of the grave was checked for possible trace evidence - in forensics these are often strands of hair, fibres, paint or fingerprints. The end of the excavation means that all the evidence are recorded, photographed, and put in an appropriate stor-

6 Lewis Somers, „Resistivity Survey," in Remote Sensing in Archaeology, ed. Jay K. Johnson (Tuscaloosa: The University of Alabama Press, 2006), 109-131; Anthony Clark, Seeing Beneath the Soil: Prospection Methods in Archaeology (London: B.T. Batsford; 1990). age. Upon the completion of the excavation, the grave pit is refilled and the place is left safe. All equipment has to be cleaned under supervision, and cleaning should be documented as a standard, to ensure that cross-site contamination cannot occur.

Differences in archaeology and forensic archaeology may be considerable, but basic methods of the field research do not differ. In forensic archaeology, especially when it embraces the study of mass graves, the term 'exhumation' is used, not just like a medico-legal term. The term 'exhumation' accentuates special attention and emphasis given to human remains, because of their identification and later, returning to the families. This does not mean that attention is not given to the context, in the sense of contextual evidence that may be relevant to the case. During the field work on individual or mass graves on archaeological sites, the term 'excavation' is used. The archaeological fieldwork has more humanistic approach and gives equal at- $\downarrow$ tention to the human remains and the context. The interpretation of the results will be thus somewhat different than in forensics. Now, the distinction between forensic excavation and forensic exhumation is clear as the difference in volume results. As archaeologists are dealing with vast time spans, it is important to detect chronology of a site, how old the findings are. Together with research of a necropolis, it is very important to reconstruct possible settlements of that precise period, and also its environmental history. Finally, one of the major questions is how people were functioning in that particular time, what can be told about their life. The dating of recent mass or individual graves also partially belongs to the field of archaeology. Since the best-known method for determining absolute age in archaeology - radiocarbon dating ${ }^{14} \mathrm{C}$ - will not give adequate results for recent findings, the classical archaeological methods of relative dating are used. Objects described in the case of an unknown soldier, such as fragments

Melissa Connor and Douglas D. Scott, "Paradigms and Perpetrators," Historical Archaeology 35, no. I. (2001): I-6. 
of clothing, emblems, arms and ammunition, help to locate this finding in a specific time period. Indeed, a number of such findings can narrow time span dating. Development of forensic taphonomy in the sense of burial environment analysis, f. e. soil analysis, opens up possibilities for a more precise dating of findings, a determination of the post-burial interval and sometimes also of the post-mortem interval. In general, different biological markers like botanical remains can be used in determination of the period between the time of deposition in the burial site and the time of recovery. ${ }^{8} \mathrm{~A}$ more specific and a very potent tool to establish the burial time in extended post-mortem period, but also to reveal possible clandestine graves, is the use of the postputrefaction fungi.' Unfortunately, in the case of an unknown soldier from Josipovac soil samples were not taken from his grave for analysis. Such an analysis could give us the information in which season of the year the body was placed in the burial pit.

As in the case of the unknown soldier, there is an intertwining of archaeology and domain of police powers when it becomes forensic archaeology. In archaeology, it is a moment when anthropological osteological remains from World War II or younger period are revealed on a site. Then the police has to be informed about the finding, which stays in a domain of forensic medicine. Also, if the police specialists find human remains and assume they are not recent, they often call archaeologists for help to resolve

8 Shari L. Forbes, „Potential Determinants of Postmortem and Postburial Interval of Buried Remains," in Soil Analysis in Forensic Taphonomy, eds. Mark Tibbett and David O. Carter (Boca Raton: CRC Press, 2008), 225-2; Heather C. Miller, Cheng-Lung Lee, Wen-Yu Lin, Henry C. Lee and Timothy M. Palmbach, „Forensic Botany: Using Plant Evidence to Aid in Forensic Death Investigation," Croatian Medical Journal 46, no. 4 (2005): 606-612.

9 David L. Hawksworth and Patricia E.J. Wiltshire, „Forensic mycology: the use of fungi in criminal investigations," Forensic Science International 206, no. I-3 (201 I): I-1 I; Shari L. Forbes, „Potential Determinants of Postmortem and Postburial Interval of Buried Remains," in Soil Analysis in Forensic Taphonomy, eds. Mark Tibbett and David O. Carter (Boca Raton: CRC Press, 2008), 225-246; Masahito Hitosugi, Kiyoshi Ishii, Takashi Yaguchi, Yuichi Chigusa, Akira Kurosu, Masahito Kido, Toshiaki Nagai and Shogo Tokudome, „Fungi can be a useful forensic tool," Legal Medicine 8, no. 4. (2006): 240-242. the dilemma. As it was said before, for archaeologists, the findings in the graves are in general more important than the skeleton and greater importance is given to them. Archaeologists admit that if they were to choose between saving an artefact or skeleton remains, they would choose the artefact. Finally, if you ask an archaeologist if there is a clearly written ethical and bioethical code that must be respected during the research, he will recognize there is not. Younger archaeologists learn from the older ones, and from the elders, they also adopt unwritten ethical rules important in their work. They are aware that excavation irreversibly destroys the possibility of another approach to the research, and that often no one can refute their interpretation because the ground has been already excavated, destroyed for further research. The same can be said for forensic archaeology - an exhumation will forever destroy the site or the crime scene; it is thus important to work according to specific protocols, methods, techniques and available technologies. The forensic excavation follows all the rules of the traditional archaeological excavation, but all steps are elaborated and elevated on a higher level with protocols and standard operating procedures (SOP's). ${ }^{1 \circ}$ This helps in resolving every day and also more unusual ethical dilemmas during the work.

Everybody claims that there should not be double standards, that skeletal remains from any historical period should be treated in the same way, with the same respect, as those from the recent wars. But then the awareness of the whole society should be at a significantly higher level. It is clear that the dead can no longer be hurt but there are still strong reasons for treating them with respect, respect for the individual.

What archaeology tells us about the future of the skeletal burials? The calculation is simple. On average, one hundred million peo-

\footnotetext{
Io Anderson Auson, Margaret Cox, Ambika Flavel, Ian Hanson, Michael Hedley, Joanna Laver, Auson Perman, Mark Viner and Richard Wright, „Protocols for the investigation of mass graves" in The Scientific Investigation of Mass Graves: Towards Protocols and Standard Operating Procedures, eds.Margaret Cox, Ambika Flavel, Ian Hanson, Joanna Laver and Roland Wessling (Cambridge: Cambridge University Press, 2008) 39-102.
} 
ple are born annually and forty million dies. If those forty million were buried in a necropolis, in a classic graveyard with skeletal burials, they would take up an area of $20 \mathrm{~km}^{2}$. One day, not in the distant future, this will become a huge problem. Will we throw our dead into the sea, or fertilize the soil with them, will we burn them?

What yesterday was ethics, today may no longer be. The rule about preserving, what we must and what we want to preserve, and our choice will represent our civilization. Whatever we thought yesterday we would preserve, if possible all of it, today has a completely different dimension. Where are the areas in which we will preserve all that? In the whirlwind of events in the recent years, more and more raises the question of how to survive, how to provide enough space and food for all, but also how to preserve everything of value? Archaeology will offer an answer based on the long history of human experience.

\section{Povzetek}

Predstavljeno delo raziskuje, do kakšne mere obstaja razlika v raziskovalni metodologiji in tehniki arheologije in forenzične arheologije. Iz zelo osnovnega razlikovanja med „izkopavanjem grobov", pojmom, ki je bliže arheološkemu smislu in „ekshumacijo človeških ostankov", tesno povezano s forenzično arheologijo, do novih modelov, ki bi lahko v prihodnosti omogočili boljšo kakovost raziskav in preiskav. $V$ zadnjih tridesetih letih so bili kot del multidisciplinarnih forenzičnih strokovnih ekip povabljeni arheologi, še posebej ob raziskavah skrivnih grobov in množičnih grobišč iz nedavnih vojn, ko je šlo za vprašanja človekovih pravic. Dobra študija prekrivanja forenzičnih in arheoloških primerov je skrivni grob neznanega vojaka iz druge svetovne vojne iz arheološkega najdišča Josipovac - Verušed pri Osijeku (Slavonija, Hrvaška). Odkrit je bil med zaščitnimi arheološkimi izkopavanji, leta 2007, na trasi avtoceste (A 5) Beli Manastir - Osijek. Najdba je bila na tem arheološkem najdišču nepričakovana, zato so bili vsi standardni postopki izvedeni že pred izkopom. Obravnavana je bila kot arheološki kontekst, saj pred izkopavanji ni bilo informacij, ki bi lahko potrdile starost, obdobje ali status pokojnika. Ko so se po opredelitvi kostnih ostankov v raziskanem kontekstu pojavili ostanki strelnega orožja, pa so se glede na to razvrstili in analizirali tudi drugi predmeti iz groba, kar je pomagalo pri kronološki, kulturni in individualni identifikaciji umrle osebe. Pomen poudarjanja konteksta je zelo pomemben, saj je omogočil razvrstitev ugotovitev v forenzični okvir. Pomembno je tudi izpostaviti razpravo o etičnih vprašanjih, saj so človeški ostanki lahko izhajajo iz arheoloških kontekstov ali pa so del uradnega postopka, ki lahko prinese pomembne dokaze za sodišče.

\section{Summary}

The present work explores to which extent the difference between research methodology and techniques of archaeology and forensic archaeology exists. From the very basic distinction between "graves excavation", a term closer to archaeological sense, and "exhumation of human remains”, closely related to forensic archaeology, to the new models that could give better quality of both research and investigations in the future. During the last thirty years, archaeologists have been called, as part of the multidisciplinary forensic expert teams in human rights cases, to investigate clandestine graves and especially mass graves from recent wars. A good case study of overlapping forensic and archaeological cases is the clandestine grave of an unknown soldier from the World War II, from the archaeological site Josipovac - Verušed near Osijek (Slavonia, Croatia). The grave was revealed during an archaeological rescue excavation in 2007 , on the route of the highway A 5 , Beli Manastir - Osijek. This finding was unexpected for an archaeological site, so all standard procedures that precede the excavation had already been made. It was treated as a real archaeological, historical layer because before excavation, there was no information that could confirm its age, period or status. So when, after defining the skeleton remains, remains of a firearm emerged from the soil, classifying and analyzing the objects from the grave helped to give chronological, cultural and individual identifiers of the deceased person. The importance of giving emphasis to the context, which enabled the classification of findings in the forensic framework, was accentuated. It is crucial to mention and discuss the ethical issues of whether the human remains are part of an archaeological period, or they are part of a case that could provide evidence for the court. 


\section{Bibliography}

Clark, Anthony. Seeing Beneath the Soil: Prospection Methods in Archaeology. London: B.T. Batsford, 1990.

Connor, Melissa and Douglas D. Scott. "Paradigms and Perpetrators." Historical Archaeology 35, no. 1 (2001): 1-6.

Cox, Margaret. Ambika Flavel, Ian Hanson, Joanna Laver and Roland Wessling. The Scientific Investigation of Mass Graves: Towards Protocols and Standard Operating Procedures. Cambridge: Cambridge University Press, 2008.

Filipec, Krešimir and Marija Šš̌a-Vivek. "Report on the archaeological site Debela suma." Hrvatski arheološki godišnjak no. 3 (2006): 69-71.

Forbes, Shari L., ,Potential Determinants of Postmortem and Postburial Interval of Buried Remains." In Soil Analysis in Forensic Taphonomy, eds. Mark Tibbett and David O. Carter, 225-246. Boca Raton: CRC Press, 2008.

Haglund, William D. "Archaeology and Forensic Death Investigations." Historical Archaeology 35, no. 1 (2001): 26-34.

Hawksworth, David L., and Patricia E.J. Wiltshire. „Forensic mycology: the use of fungi in criminal investigations." Forensic Science International 206, no. I-3 (20II): I-II.

Hitosugi, Masahito, Kiyoshi Ishii, Takashi Yaguchi, Yuichi Chigusa, Akira Kurosu, Masahito Kido, Toshiaki Nagai and Shogo Tokudome. „Fungi can be a useful forensic tool." Legal Medicine 8, no. 4. (2006): 240242.

Miller, Heather C., Cheng-Lung Lee, WenYu Lin, Henry C. Lee and Timothy M. Palmbach. „Forensic Botany: Using Plant Evidence to Aid in Forensic Death Investigation." Croatian Medical Journal 46, no. 4 (2005): 606-612.
Petrov, Marinko. Pakao na Dravi Belišće 19441945 Bistrinci. Bački Petrovac: Mesno udružnje boraca NOR-a Belišće, 1979.

Scott, Douglas D., and Melissa Connor. "The Role and Future of Archaeology in Forensic Science." Historical Archaeology 35, no. 1 (2001): 101-04.

Somers, Lewis. „Resistivity Survey.“ In Remote Sensing in Archaeology, ed. Jay K. Johnson, I09-I3I. Tuscaloosa: The University of Alabama Press, 2006.

Tibbett, Mark and David O. Carter, eds. Soil Analysis in Forensic Taphonomy. Boca Raton: CRC Press; 2008.

\section{Abbreviations}

Hist Archaeol.=Historical Archaeology Croat Med J = Croatian Medical Journal Forensic Sci It = Forensic Science International Legal Med $=$ Legal Medicine 


\section{NAVODILA ZA AVTORJE}

Revija objavlja primarno v slovenskem jeziku, toda tudi v večjih svetovnih jezikih (angleščina, nemščina, francoščina, italijanščina, ruščina). V objavo se sprejmejo tudi članki v cirilici. V primeru tujejezičnega članka morata biti izvleček in povzetek poleg angleščine obvezno v slovenskem jeziku. Za oboje poskrbi avtor.

Članek (praviloma v obsegu 7000 , vendar največ 10.000 besed) naj ima na začetku: 1) naslov ter ime in priimek avtorja/-ice; 2) izvleček v slovenskem in abstract angleškem jeziku, do 250 besed; 3 ) ključne besede v slovenščini in angleščini (do 5); 4) kratko predstavitev avtorja/-ice (do roo besed v slovenščini in angleščini), navedena naj bo tudi organizacija zaposlitve. Članek naj po razpravnem besedilu vsebuje še: I) povzetek v slovenščini in angleščini ter 2) seznam virov in literature.

Prispevki naj bodo napisani v knjižni slovenščini (ali v knjižni različ̌ici katerega tujih jezikov, v kolikor gre za tujejezično delo) ob upoštevanju veljavnega pravopisa, v nasprotnem primeru si uredništvo pridržuje pravico, da članka ne recenzira oziroma ga zavrne.

Če je prispevek že bil objavljen v kaki drugi reviji ali če čaka na objavo, je treba to izrecno navesti.

Prispevek naj ima dvojni medvrstični razmik, tip črk naj bo Times New Roman, velikost 12 pik (v opombah 10). Besedilo naj bo levo poravnano, strani pa zaporedno oštevilčene. Odstavki naj bodo ločeni s prazno vistico.

Uporabiti je mogoče do tri hierarhične nivoje podnaslovov, ki naj bodo ośtevilčeni (uporabljajte izključno navaden $s l o g$, v prelomu bodo ravni ločene tipografsko): I. - I.I - I.I.I

Za poudarke uporabite izključno ležeći tisk(v primeru jezikoslovnih besedil, kjer so primeri pravilomavležečem tisku, lahkoza poudarke izjemoma uporabite polkrepki tisk). Ležeče pišite tudi besede v tujih jezikih. Raba drugih tipografskih rezov (podčrtano, velike male črke, krepko kurzivno ...) ni dovoljena. Ne uporabljajte dvojnih presledkov, prav tako ne uporabljajte preslednice za poravnavo besedila. Edina oblika odstavka, ki je dovoljena, je odstavek z levo poravnavo brez rabe tabulatorjev prve ali katerekoli druge vrstice v ostavku (ne uporabljajte sredinske, obojestranske ali desne poravnave odstavkov). Oglate oklepaje uporabljajte izključno za fonetične zapise oz. zapise izgovarjave. Tri pike so stične le, če označujejo prekinjeno bese... Pri nedokončani misli so tri pike nestične in nedeljive ... Prosimo, da izključite funkcijo deljenja besed.

Sprotne opombe naj bodo samooštevilčene (številke so levostično za besedo ali ločilom - če besedi, na katero se opomba nanaša, sledi ločilo) in uvrščene na tekočo stran besedila.

Citati v besedilu naj bodo označeni z dvojnimi (» «), citati znotraj citatov pa z enojnimi (") narekovaji. Izpuste iz citatov in prilagoditve označite s tropičjem znotraj poševnic /.../. Daljše citate (več kot s vrstic) izločite v samostojne odstavke, ki jih od ostalega besedila ločite $\mathrm{z}$ izpustom vrstice in umikom $\mathrm{v}$ desno. Vir citata označite $\mathrm{v}$ okroglem oklepaju na koncu citata. Če je avtor/-ica naveden/-a v sobesedilu, priimek lahko izpustite.
V besedilu označite najprimernejša mesta za likouno opremo (tabele, slike, skice, grafikone itd.) po zgledu: [Tabela I približno tukaj]. Posamezne enote opreme priložite vsako v posebni datoteki (v.eps, ai, .tif ali .jpg formatu, minimalna resolucija $300 \mathrm{dpi}$, tabele prilagajte v posebni datotetki v formatu .doc, grafe pa v formatu .xls, kjer naj ob grafu stoji tabela, ki je podlaga za graf). Naslov tabele je nad tabelo, naslov grafa/slike pa pod grafom/sliko.

Prostor, ki ga oprema v prispevku zasede, se šteje v obseg besedila, bodisi kot 250 besed (pol strani) ali 500 besed (cela stran).

Ob oddaji preda avtor uredništvu članek v formatu .doc in hkrati tudi.pdf.

Za citiranje literature in za pripravo seznama uporabljene literature se uporablja izkljucno stil Chicago, in sicer v obliki, kot je aktualna, tj. v svoji i6. izdaji (http://www.chicagomanualofstyle.org/home.html, 16. izdaja na razpolago na zahtevo tudi pri uredniku izdaje)

I: Enoavtorska monografija

a) Polna oblika reference pod crrto: Michael Pollan, The Omnivore's Dilemma: A Natural History of Four Meals (New York: Penguin, 2006), 99-100.

b) Kratka oblika reference pod črto: Pollan, Omnivore’s Dilemma, 3 .

c) Navedba v virih in literaturi: Pollan, Michael. The Omnivore's

Dilemma: A Natural History of Four Meals. New York: Penguin, 2006. II: Većavtorska monografija

a) Polna oblika reference pod črto: Geoffrey C. Ward and Ken Burns, The War: An Intimate History, 1941-1945 (New York: Knopf, 2007), 52

b) Navedba v virih in literaturi: Ward, Geoffrey C., and Ken Burns. The War: An Intimate History, 1941-1945. New York: Knopf, 2007.

III: Knjiga z urednikom

a) Polna oblika reference pod črto: Joel Greenberg, ed., Of Prairie, Woods, and Water: Two Centuries of Chicago Nature Writing (Chicago: University of Chicago Press, 2008), 42.

b) Kratka oblika reference pod črto: Greenberg, Prairie, Woods, and Water, 326-27.

c) Navedba v virih in literature: Greenberg, Joel, ed. Of Prairie, Woods, and Water: Two Centuries of Chicago Nature Writing. Chicago: University of Chicago Press, 2008.

IV: Poglavje v knjigi

a) Polna oblika reference pod črto: Glenn Gould, "Streisand as Schwarzkopf," in The Glenn Gould Reader, ur. Tim Page (New York: Vintage, 1984),310.

b) Kratka oblika reference pod črto: Gould, "Streisand as Schwarzkopf," 309 .

c) Navedba v virih in literaturi: Gould, Glenn. "Streisand as Schwarzkopf." In The Glenn Gould Reader, ur. Tim Page, 308-11. New York: Vintage, 1984 .

Gould, "Streisand as Schwarzkopf," 309 
V: Clanek v reviji

a) Polna oblika reference pod črto: Walter Blair, "Americanized Comic Braggarts," Critical Inquiry 4, no. 2 (1977):331-32.

b) Kratka oblika reference pod črto: Blair, "Americanized Comic Braggarts," 335 .

c) Navedba v virih in literaturi: Blair, Walter. "Americanized Comic Braggarts." Critical Inquiry 4, no. 2 (1977): 331-49.

VI: Clanek v reviji (digitalna objava; DOI)

a) Polna oblika reference pod črto: William J. Novak, "The Myth of the 'Weak' American State," American Historical Review Ir3 (June 2008): 758, doi:10.1086/ahr.113.3.752.

b) Kratka oblika reference pod črto: Novak, "Myth," 770 .

c) Navedba v virih in literaturi: Novak, William J. "The Myth of the 'Weak' American State." American Historical Review 113 (June 2008): 752--72. doi:10.1086/ahr.113.3.752., "Streisand as Schwarzkopf," 309.

VII: Članek v reviji (digitalna objava, URL)

a) Polna oblika reference pod črto: Wilfried Karmaus and John F. Riebow, "Storage of Serum in Plastic and Glass Containers May Alter the Serum Concentration of Polychlorinated Biphenyls," Environmental Health Perspectives II2 (May 2004): 645, http://www. jstor.org/stable/3435987 (datum dostopa do spletne strani).

b) Navedba v virih in literaturi: Karmaus, Wilfried, and John F. Riebow. "Storage of Serum in Plastic and Glass Containers May Alter the Serum Concentration of Polychlorinated Biphenyls." Environmental Health Perspectives II2 (May 2004): 643--47. http:// www.jstor.org/stable/3435987.

O morebitnih drugih posebnostih se posvetujte z uredništvom

Naslov uredništva: dr. Gregor Pobežin, Fakulteta za humanistične študije Univerze na Primorskem, Titov trg 5,

SI-6000 Koper, gregor.pobezin@fhs.upr.si 

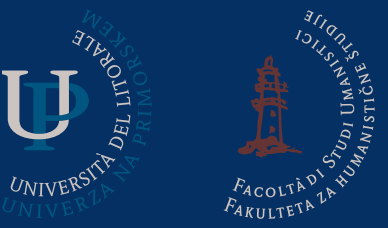

Založba Univerze na Primorskem www.hippocampus.si ISSN 2350-5443

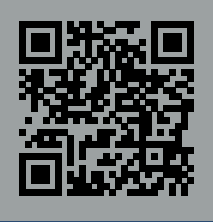

